\title{
Kesalahan Siswa Dalam Menyelesaikan Soal Cerita Materi Pecahan Ditinjau Dari Kemampuan Matematis
}

\author{
Ilham Ali Fikri*, Khamdun, Himmatul Ulya \\ Universitas Muria Kudus, Indonesia \\ *Coresponding Author: ilhamaly69@gmail.com
}

Article History:

Received 2021-12-04

Revised 2022-01-15

Accepted 2022-02-01

DOI:

10.31949/educatio.v8i1.1796

\begin{abstract}
One of the skills tanght in mathematics is problem solving skills. This ability is very important because it can belp students' difficulties that are often found in everyday life. The purpose of this study was to describe students' errors in working on math story problems on fractions in terms of low, medium, and high mathematical abilities. The type of research method used is descriptive qualitative. This research was conducted in the fifth grade of SD 5 Bae Kudus by taking students as research subjects. Data were collected through observation, interviews, documentation, and recording. The results of this study indicate that students with low mathematical abilities tend to make almost all types of errors, starting from understanding problems, transforming problems, calculating processes, and writing answers. Meanwhile, students with high mathematical ability made a few mistakes. They tend to be able to solve fraction problems that are packeaged in story problems. The conclusion of this research is that mathematical ability is needed in solving math problems presented in the story.

Keywords: error analysis; story matters; fractions; mathematical ability.
\end{abstract}

\begin{abstract}
Abstrak
Salah satu kemampuan yang diajarkan dalam matematika adalah kemampuan pemecahan masalah. Kemampuan ini sangat penting karena dapat membantu kesulitan siswa yang sering ditemukan dalam kehidupan sehari-hari. Tujuan penelitian ini adalah untuk mendeskripsikan kesalahan siswa dalam mengerjakan soal cerita matematika pada pecahan ditinjau dari kemampuan matematis dari yang rendah, sedang, dan yang tinggi. Jenis metode penelitian yang digunakan adalah deskriptif kualitatif. Penelitian ini dilaksanakan pada kelas V SD 5 Bae Kudus dengan mengambil subjek siswa sebagai subjek penelitian. Data dikumpulkan melalui observasi, wawancara, dokumentasi, dan pencatatan. Hasil dari penelitian ini menunjukkan siswa dengan kemampuan matematis rendah cenderung melakukan hampir semua tipe kesalahan mulai dari memahami masalah, transformasi masalah, proses perhitungan, dan penulisan jawaban. Sedangkan siswa dengan kemampuan matematis tinggi sedikit melakukan kesalahan. Mereka cenderung mampu menyelesaikan soal pecahan yang dikemas dalam soal cerita. Kesimpulan dari penelitian ini adalah bahwa kemampuan matematis sangat diperlukan dalam menyelesaikan soal matematika yang disajikan dalam cerita.
\end{abstract}

Kata Kunci: analisis kesalahan; soal cerita; pecahan; kemampuan matematis.

\section{PENDAHULUAN}

Matematika adalah ilmu yang wajib diberikan kepada siswa di sekolah dasar. Matematika sangat penting untuk membantu memahami fenomena-fenomena yang sering ditemukan pada kehidupan sehari-hari (Henn, 2007; Gooding, 2009: Seifi, et al, 2012; Yavuz Mumcu, 2018). Secara sadar maupun tidak sadar, setiap hari kita dihadapkan dengan berbagai permasalahan yang menuntut kemampuan pemecahan masalah (Utami \& Helmi, 2017). Pemecahan masalah dalam matematika membantu siswa untuk mengalami bagaimana menyelesaikan masalah kehidupan sehari-hari dengan menerapkan pengetahuan dan keterampilan matematika mereka (Osman, et al., 2018). Siswa perlu memiliki kemampuan memecahkan masalah matematika karena menjadi kebutuhan dalam kurikulum matematika di seluruh dunia (Liljedah, et al., 2016). Kemampuan pemecahan masalah dapat membantu siswa mengatasi kesulitan-kesulitan yang dihadapi untuk mencapai 
tujuan yang diharapkan (Sumartini, 2019; Putri, et al., 2019). Oleh karena itu, dalam aktivitas pembelajaran matematika guru perlu mengenalkan siswa permasalahan matematika, karena dengan menghadapi masalah siswa akan dituntut untuk berpikir secara intensif dan kreatif dalam menyelesaikan masalah yang dihadapinya (Elita, et al., 2019). Guru matematika harus memfasilitasi siswanya untuk belajar berpikir melalui literatur yang ada (Shadiq, 2014), dan pembelajaran matematika tidak terlepas dengan materi operasi hitung, operasi penjumlahan, pengurangan, perkalian maupun pembagian, semua itu salah satunya terkait dengan materi bilangan pecahan.

Operasi hitung pada bilangan cacah, bilangan bulat, maupun pecahan telah diajarkan di sekolah dasar. Hal ini dikarenakan bahwa operasi hitung pada bilangan cacah, bilangan bulat, maupun pecahan sangat berperan dalam berbagai hitung matematika. Dalam mengajarkan masalah matematika, biasanya guru memberikan soal non rutin yang disajikan dalam bentuk cerita dan berkaitan dengan keadaan yang dialami siswa dalam kehidupan sehari-hari yang di dalamnya terkandung konsep matematika (Rahardjo \& Waluyati, 2011). Fattahillah et al. (2017) Terdapat beberapa kesalahan yang dilakukan siswa dalam menyelesaikan soal matematika berdasarkan teori Newman yaitu kesalahan membaca (reading error), kesalahan memahami soal (comprehension), kesalahan tranformasi (tranformation errors), kesalahan proses perhitungan (procces skill errors), dan kesalahan penulisan jawaban (encoding errors).

Keterampilan siswa dalam menyelesaikan soal cerita sangat berguna dalam pembelajaran kehidupan sehari-hari, namun tidak semua siswa dapat dengan mudah mengerjakan soal cerita, karena setiap siswa mempunyai kemampuan matematis yang berbeda-beda. Kemampuan matematis yang dimaksud adalah kemampuan yang dibutuhkan untuk melakukan berbagai aktivitas mental berpikir, menela'ah, memecahkan masalah siswa dalam menyelesaikan soal-soal matematika. Depdiknas (Agustina., 2016) membuat kriteria tingkat kemampuan siswa dan skala penilaiannya menjadi 3 kategori yaitu kemampuan tinggi jika nilai yang diperoleh 80-100, kemampuan sedang jika nilai yang diperoleh 65-79, dan kemampuan rendah jika nilai yang di peroleh 0-64. Maka dari itu kemampuan matematis merupakan salah satu hal yang penting dalam matematika karena sangat berpengaruh pada keterampilan siswa dalam menyelesaikan soal.

Berdasarkan hasil penelitian Suprapti (2012) menunjukkan bahwa 59,09\% siswa kelas 6 SD Bandung Rejosari melakukan kesalahan ketika menyelesaikan soal pecahan campuran. Kesalahan-kesalahan yang dilakukan siswa terjadi tidak begitu saja melainkan adanya sesuatu penyebab mengapa siswa melakukan suatu kesalahan tersebut. Usodo (2001) menemukan beberapa faktor penyebab kesalahan siswa dalam menyelesaikan soal pecahan, salah satunya yaitu siswa tidak mengetahui algoritma yang tepat dalam menyelesaikan soal operasi hitung pecahan sehingga siswa tidak menyadari bahwa apa yang dilakukan dalam menyelesaikan soal merupakan sebuah kesalahan. Penelitian Fatahillah et al. (2017) menunjukkan bahwa pada umumnya siswa yang melakukan kesalahan adalah siswa yang tidak memahami konsep dan memahami masalah.

Masalah dalam mengerjakan soal cerita materi pecahan juga terjadi pada SD 5 Bae Kudus. Dari hasil observasi ditemukan masih banyak siswa yang melakukan kesalahan dalam mengerjakan soal cerita pecahan mulai dari memahami soal, mencari cara penyelesaian, sampai menulis jawaban. Kesulitan yang dialami siswa ini menyebabkan hasil belajar menjadi tidak maksimal. Dari keterangan guru guru yang mengajar di SD 5 bae dalam wawncara, ada indikasi bahwa penguasaan konsep siswa dalam mengerjakan soal cerita materi pecahan masih tergolong rendah. Hal ini ditunjukkan dengan masih banyaknya siswa yang masih kesulitan dalam menyelesaikan soal-soal cerita yang terkait dengan konsep dan sifat operasi bilangan pecahan.

Penelitian ini akan melakukan analisis kemampuan siswa SD 5 Bae Kudus dalam menyelesaikan masalah matematika dalam materi pecahan. Penelitian ini diharapkan dapat memberikan gambaran kesalahankesalahan apa saja dilakukan siswa dalam memecahkan masalah matematika jika ditinjau dari kemampuan matematisnya.

\section{METODE PENELITIAN}

Metode penelitian yang digunakan dalam penelitian ini adalah metode kualitatif deskriptif. Penelitian ini dilaksanakan pada bulan Juli 2021 di SD 5 Bae, Kecamatan Bae, Kabupaten Kudus. Dalam penelitian ini 
akan menganalisis apa saja kesalahan siswa saat mengerjakan soal cerita materi pecahan yang ditinjau dari kemampuan matematis pada kelas V SD 5 Bae. Subjek penelitian ini yakni siswa kelas V SD 5 Bae.

Sumber data yang diambil yaitu sumber data primer dan data sekunder. Sumber data primer diperoleh dari observasi dan wawancara yang didapat dari informan di lingkungan SD 5 Bae yaitu guru dan siswa kelas V SD 5 Bae. Sumber data sekunder diperoleh dari dokumentasi penelitian, catatan penelitian, dan data pendukung lainnya. Sedangkan teknik pengumpulan data dalam penelitian ini dilakukan dengan metode observasi, wawancara terstruktur, dokumentasi, dan pencatatan.

\section{HASIL DAN PEMBAHASAN}

Penelitian ini dilakukan pada saat pandemi Covid-19, membuat siswa belajar secara online dan masuk sekolah satu kali dalam seminggu. Itu sangat berdampak pada hasil belajar siswa, dari hasil pengamatan pada saat dilapangan banyak siswa yang mulai lupa tentang materi apa saja yang pernah disampaikan oleh guru. Sehingga saat ini siswa lebih membutuhkan perhatian lebih dari guru untuk mengingatkan kembali apa saja yang telah dipelajari selama ini.

Penelitian ini membahas mengenai kesalahan siswa dalam mengerjakan soal cerita matematika materi pecahan ditinjau dari kemampuan matematis. Kesalahan yang dianalisis dalam penelitian ini didasarkan pada teori Newman yang meliputi kesalahan membaca, kesalahan memahami masalah, kesalahan transformasi, kesalahan proses perhitungan, dan kesalahan penulisan jawaban. Sedangkan standar kemampuan matematis siswa menganut standar dari Depdiknas (Agustina, 2016) yaitu mulai dari kemampuan matematis rendah dengan nilai 0-64, kemampuan matematis sedang 65-79 dan kemampuan matematis tinggi dengan nilai 80100.

Data dalam penelitian ini diperoleh dari hasil tes soal cerita materi pecahan dan wawancara dengan siswa di SD 5 Bae Kudus, jumlah murid di kelas tersebut adalah 20 siswa. selanjutnya dari 20 siswa tersebut dipilih 6 orang siswa yang masing-masing memiliki kemampuan matematika dari rendah sampai ke yang tinggi. Jawaban dari subjek penelitian tersebut kemudian dianalisis secara intensif mengenai jenis kesalahannya. Selain itu untuk memperkuat data, subjek penelitian tersebut juga diwawancarai untuk mengkonfirmasi kesalahan dan menemukan penyebab kesalahan yang dilakukan siswa. Tabel 1 merupakan hasil nilai 6 orang siswa.

Tabel 1. Nilai siswa

\begin{tabular}{cc}
\hline Nama & Nilai \\
\hline AFS & 24 \\
NAH & 68 \\
NAF & 24 \\
SDA & 36 \\
TFKP & 72 \\
YMC & 84 \\
\hline
\end{tabular}

Berdasarkan hasil analisis kesalahan siswa kelas V SD 5 Bae terdapat empat kesalahan yaitu tahap memahami masalah, transformasi masalah, proses perhitungan, dan penulisan jawaban. Pada penelitian ini tidak di temukan adanya kesalahan siswa dalam proses membaca soal karena pada umumnya kemampuan membaca siswa untuk kelas 5 SD sudah cukup baik. Berikut adalah hasil penelitian:

1. Kesalahan Siswa Berkemampuan Matematis Rendah Dalam Menyelesaikan Soal Cerita Materi Pecahan

Berdasarkan data temuan penelitian terdapat tiga dari enam siswa yang mempunyai tingkat kemampuan matematis rendah (Nilai 0-64). Siswa dengan kemampuan matematis rendah cenderung melakukan kesalahan paling banyak pada tahap memahami masalah sebanyak 7 kali terdiri tiga indikator yaitu salah menuliskan yang diketahui, salah menuliskan ditanya, dan salah menuliskan keduanya. Kedua adalah kesalahan proses perhitungan sebanyak 4 kali terdiri dari dua indikator yakni salah menentukan penyebut dan salah dalam menggunakan metode penyelesaian. Ketiga kesalahan penulisan jawaban sebanyak 3 kali dengan dua indikator 
yakni siswa tidak menuliskan kesimpulan jawaban akhir dan siswa tidak menuliskan satuan dengan benar. Keempat kesalahan transformasi masalah sebanyak 1 kali dengan indikator menuliskan operasi hitung dengan format yang salah.

2. Kesalahan Siswa Berkemampuan Matematis Sedang Dalam Menyelesaikan Soal Cerita Materi Pecahan

Berdasarkan data temuan penelitian terdapat dua dari enam siswa yang mempunyai tingkat kemampuan matematis sedang (Nilai 64-79). Siswa dengan kemampuan matematis sedang cenderung melakukan kesalahan paling banyak pada tahap perhitungan sebanyak 3 kali dengan indikator siswa salah dalam menggunakan metode pembagian pecahan. Kedua adalah kesalahan penulisan jawaban sebanyak 2 kali dengan indikator siswa tidak menuliskan satuan dengan benar. Ketiga adalah transformasi masalah sebanyak 1 kali dengan indikator siswa tidak dapat menentukan operasi hitung dengan benar.

3. Kesalahan Siswa Berkemampuan Matematis Tinggi Dalam Menyelesaikan Soal Cerita Materi Pecahan

Berdasarkan data temuan penelitian terdapat satu dari enam siswa yang mempunyai tingkat kemampuan matematis tinggi (Nilai 80-100). Siswa dengan kemampuan matematis tinggi pada penelitian ini hanya melakukan satu kesalahan yaitu pada tahap transformasi masalah dengan indikator siswa menuliskan operasi hitung dengan format yang salah.

Hasil dari penelitian ini menunjukkan bahwa ada sejumlah 22 seluruh kesalahan yang dilakukan oleh siswa. siswa berkemampuan matematis rendah cendrung paling banyak melakukan kesalahan pada tahap memahami masalah sebanyak 7 Kali, proses perhitungan sebanyak 4 kali, penulisan jawaban sebanyak 3 kali, dan transformasi masalah sebanyak 1 kali. Setelah itu siswa berkemampuan matematis sedang yaitu melakukan kesalahan pada proses perhitungan sebanyak 3 kali, proses penulisan jawaban sebanyak 2 kali, dan transformasi masalah sebanyak 1 kali. Terakhir siswa berkemampuan matematis tinggi melakukan kesalahan pada transformasi soal sebanyak 1 kali. Siswa dengan kemampuan matematis rendah cenderung melakukan hampir semua tipe kesalahan mulai dari memahami masalah, transformasi masalah, proses perhitungan, dan penulisan jawaban. Kesalahan memahami masalah merupakan kesalahan yang paling banyak dilakukan oleh siswa berkemampuan rendah. Siswa berkemampuan matematis sedang, melakukan melakukan tiga tipe kesalahan yaitu mulai dari kesalahan transformasi masalah, proses perhitungan dan penulisan jawaban. Kesalahan proses perhitungan merupakan kesalahan yang paling banyak dilakukan oleh siswa berkemampuan matematis sedang. Sedangkan siswa dengan kemampuan matematis tinggi hanya melakukan satu kesalahan yaitu pada tahap transfomasi masalah. Temuan penelitian ini sekaligus mendukung penelitian yang dilakukan oleh Fatahillah et al (2017) yang menyatakan bahwa penyebab paling tinggi kesalahan siswa dalam menyelesaikan soal cerita adalah mereka tidak memahami konsep dan masalah. Hal ini menyebabkan siswa kesulitan dalam melakukan transformasi masalah, keterampilan proses dan membuat kesimpulan.

\section{KESIMPULAN}

Siswa dengan kemampuan matematis rendah cenderung melakukan hampir semua tipe kesalahan. Kesalahan memahami masalah merupakan kesalahan yang paling banyak dilakukan oleh siswa berkemampuan rendah. Pada siswa berkemampuan matematis sedang, kesalahan proses perhitungan merupakan kesalahan yang paling banyak dilakukan. Sedangkan siswa dengan kemampuan matematis tinggi hanya melakukan satu kesalahan yaitu pada tahap transfomasi masalah. Dengan demikian, dapat disimpulkan kemampuan matematis sangat diperlukan dalam menyelesaikan soal matematika yang disajikan dalam cerita.

\section{DAFTAR PUSTAKA}

Agustina, A. (2016). Proses Berpikir Siswa Dalam Memecabkean Masalah Matematika Berdasarkan Tingkat Kemampuan Siswa Pada Materi Pokok Operasi Aljabar Kelas Viii Smp Mubammadiyab Kediri. Skripsi tidak di terbitkan. Kediri: Program Studi Pendidikan Matematika UNP Kediri.

Elita, G. S., Habibi, M., Putra, A., \& Ulandari, N. (2019). Pengaruh Pembelajaran Problem Based Learning dengan Pendekatan Metakognisi terhadap Kemampuan Pemecahan Masalah Matematis. Mosharafa: Jurnal Pendidikan Matematika, 8(3), 447-458. 
Fatahillah, A., Wati, Y. F., \& Susanto, S. (2017). Analisis kesalahan siswa dalam menyelesaikan soal cerita matematika berdasarkan tahapan newman beserta bentuk scaffolding yang diberikan. Kadikma, $8(1)$, 40-51.

Gooding, S. (2009). Children"s difficulties with mathematical word problems. University of Cambridge, UK. Joobert M (Ed). Proceeding of The British Society for Research into Learning Mathematics, 29(3).

Henn, H. W. (2007). Modelling in school-chances and obstacles. The Monhana Mathematics Enthusiast, Monograph, 3, 125-138.

Liljedah, P., Trigo, M. S., Malaspina, U., \& Bruder, R. (2016). Problem Solving in Mathematics Education. Hamburg: Springer Open.

Osman, S., Yang, C. N. A. C., Abu, M. S., Ismail, N., Jambari, H., \& Kumar, J. A. (2018). Enhancing students' mathematical problem-solving skills through bar model visualisation technique. International Electronic Journal of Mathematics Education, 13(3), 273-279.

Putri, R. S., Suryani, M., \& Jufri, L. H. (2019). Pengaruh Penerapan Model Problem Based Learning terhadap Kemampuan Pemecahan Masalah Matematika. Mosharafa: Jurnal Pendidikan Matematika, 8(2). 331340.

Rahardjo, M. \& Waluyati, A. (2011). Pembelajaran Soal Cerita Operasi Hitung Campuran di Sekolah Dasar. Yogyakarta: Pusat Pengembangan dan Pemberdayaan Pendidik dan Tenaga Kependidikan Matemtika.

Seifi, M., Haghverdi, M., \& Azizmohamadi, F. (2012). Recognition of students' difficulties in solving mathematical word problems from the viewpoint of teachers. Journal of Basic and Applied Scientific Research, 2(3), 2923-2928.

Shadiq, F. (2014). Pembelajaran Matematika (Cara Meningkatkan Kemampuan Berpikir Siswa). Yogyakarta: Graha Ilmu.

Sumartini, T. S. (2016). Peningkatan kemampuan pemecahan masalah matematis siswa melalui pembelajaran berbasis masalah. Mosharafa: Jurnal Pendidikan Matematika, 5(2), 148-158.

Suprapti. (2012). Analisis Kesalahan Siswa Dalam Mengerjakan Soal operasi bitung di SDN Bandungrejosari 1. Skripsi tidak diterbitkan. Malang : Program Studi Dan Pendidikan Guru Sekolah Dasar UNM.

Usodo, B. (2001). Diagnosis Kesulitan Belajar Topik Pecahan dan Alternatif Pemecahannya. Tesis tidak diterbitkan:Pasca UNESA.

Utami, C. T. \& Helmi, A. F. (2017). Self-Efficacy dan Resiliensi: Sebuah Tinjauan Meta-Analisis. Buletin Psikologi. 25 (1), pp. $54-65$.

Yavuz Mumcu, H. (2018). Examining Mathematics Department Students' Views on the Use of Mathematics in Daily Life. International Online Journal of Education and Teacbing (IOJET), 5(1), 61-80. 